\title{
Capacity of Local Public Institutions in Lake Management: Case of Lake Hawassa
}

\author{
Amde Faris \\ Urban Environment and Climate Change Management, Ethiopian Civil Service University, Addis Ababa, Ethiopia \\ Email address: \\ farisamde@yahoo.com \\ To cite this article: \\ Amde Faris. Capacity of Local Public Institutions in Lake Management: Case of Lake Hawassa. International Journal of Environmental \\ Protection and Policy. Vol. 7, No. 5, 2019, pp. 127-136. doi: 10.11648/j.jjepp.20190705.11
}

Received: September 24, 2019; Accepted: April 29, 2019; Published: November 25, 2019

\begin{abstract}
Lake Hawassa is fresh water and located within the Ethiopian Rift Valley. It has social and economic significance to the City of Hawassa and community within the catchment. For effective management of this lake, the local public institutional aspect which play significant role in the overall management of lake needs to be understood. Local government institutions that direct management actions, coordinates stakeholders in the management and implements rules and regulations are increasingly considered as the solution for natural resource management. Within this context, the aim of the study was to assess capacity of local public institutions to manage Lake Hawassa. Specifically the study has aimed for the analysis of institutional and legal framework, resource capacity, to probe stakeholder integrations in the management of the lake, and to look out mechanisms of public awareness and education programs, using qualitative and quantitative approaches. In the view of answering research questions the researcher employed both descriptive and explanatory research. Through the use of questionnaires, interviews, focus group discussion, document review and observations local public institutional capacity in lake management were identified. The findings of the study revealed that present local public institutional structure and their capacity were weak to effectively manage Lake Hawassa. There is limited enforcement of the legislative provisions such as river basin organization and water regulation proclamations. The study has also found out that there is also absence of regionally established EIA, pollution control and investment proclamations to manage natural resources. The findings of the study also indicated weak linkage of stakeholders, limited public awareness and constraints of environmental education program as other institutional problems for sustainable management of the lake. It is evident from this study that local public institution has limited in their framework and capacity for sustainable management of the lake. Thus, creating institutional structure and building their human, financial and technological capacity are necessary for effective management of the lake. It is also significant to promote strong inter- sectoral and multi-stakeholders integration in the management of Lake Hawassa.
\end{abstract}

Keywords: Capacity, Stakeholder, Management, Lake, Hawassa, Institution

\section{Introduction}

Public institutions and their capacity matters in natural resource management because governments in any country work through their structured organizations to perform their functions. United Nation advocates that governments are effective instruments for environmental conservation and therefore accept institution as building a major effort for promoting constituent economic and social progress, and for better environmental management. Comprehensive lake management strategies should include sound policy and institutional frameworks, effective organizational arrangements and clear and transparent procedures for resolving conflicts and inequities that may arise over resources allocation and management actions. Managing lake needs to be guided by a common long-term vision. For lakes to continue to provide benefits into the future requires a comprehensive management approach involving all stakeholders and covering all activities affecting the water resources throughout the watershed. To work effectively, management plans must be developed at the community level, involve the participation of all the groups who benefit directly and indirectly from the water bodies, and have clear and transparent procedures for resolving conflicts. As Acheson (2006) argues that many of the world's natural 
resources are in a state of crisis. The solution to this crisis is to develop effective management institutions, but still there is no consensus on what those institutions are. Some economists favor solving resource-management problems through the institution of private property; others advocate central government control; and many anthropologists advocates local-level management as the solution. According to UNEP (2012) a central philosophy of an integrated approach to water resources management is that water should be managed at the lowest appropriate level. This means taking a basin approach where appropriate and decentralizing decision making, usually with increasing input and role for various stakeholders with an interest in how water resources are allocated and management decisions are being made. It is also believed that an integrated approach is necessary both to take into account the different interests, concerns and experience in water resources and management and to improve efficiency in investment decisions.

The Ethiopian environmental policy also considered natural resources as the base of the economy and in the Growth and Transformation Plan (2010) key concern is given to environmental conservation for sustainable development. In this plan building a 'Green and Climate Change Resistant Economy' and ongoing implementation of environmental laws are the key strategic directions to be pursued during the plan period.

To this end Lake Hawassa lies between two rapidly growing cities of Hawassa and Shashemene, as result this water resource is influenced by different anthropogenic activities which results in the degradation of the lake. Hence, to take appropriate measures local institutional frameworks, capacity and their ability to integrate stakeholders as part of management are essential for successful management. On the other aspect, the lake covers large geographic area within regional state of SNNPRS and Oromiya. Consequently, intersectoral integration within government institutions and further partnership with other stakeholders has fundamental importance for the sustainability of this fresh water resource.

According to Ethiopian Biodiversity Conservation Institute urban expansion, deforestation, land degradation, industrial and municipal waste, lake side farming and sedimentation have been identified as major threats to the lake (Amare, 2005). However, the institutional component of managing Lake Hawassa received less attention. The role of public institution and their capacity in solving environmental problem was not well assessed in the study area, which shows that there is knowledge gap. Hence it is important to identify and analyze the capacity of local public institutions in the management of Lake Hawassa.

\section{Research Methods}

This study used a combination of methods. The researcher used both primary and secondary data collection methods.
Questionnaires: Questionnaires were used to gather the views of public institution experts. The critical measurement issues covered through the questionnaires were; the institutional and legal frameworks, resource aspect, practices of stakeholder integration and methods of public awareness program.

Interviews: Interviews were also conducted with selected government officials as a primary source of data collection. Interview questions, which designed to assess the management practice of the lake, implementation of legal provisions and combinations among government sectors in the management of the lake were some of the topics discussed in the interview.

Focus group discussion: The stakeholders of MSE that runs their business around the shore of lake, 'Lake Side Youth Association' and 'Sidama' Development Association were represented through focus group discussion. The major issues raised during the discussion includes level of stakeholders integration, their observation towards changing situation of Lake Hawassa, attention given to the lake in the aspect of management and measures that could be taken to effectively manage the lake.

Document Review: In the study the most relevant documents to lake management were used as source of data. Some of the documents used in this study include FDRE policy and legal documents and SNNPRS different legislative provision.

Field Observation: The field observations were conducted to gather and identify the necessary information for the study by using checklists. During the field assessment, the checklist was used to look the existing management mechanisms, and to assess methods of public awareness tools used for the management of the lake.

\section{Data Analysis and Presentation}

The data which were collected through questionnaires in the study were analyzed using descriptive statistics techniques such as frequency distribution and percentages. The qualitative data gathered by interview and focus group discussion were interpreted through narrative analysis. In addition, legislative documents related to water and natural resources were analyzed as document review. The collected primary and secondary data were presented through using frequency table, figures, graph and photographs.

\section{Results}

\subsection{Response Rate}

In this study the sample size for survey was 48, for interview was five and 32 focus group discussions were addressed. All respondents, except four returned the questionnaire. 
Table 1. Response Rate for the Questionnaires.

\begin{tabular}{|c|c|c|c|}
\hline Sector & Questionnaires Distributed & Questionnaires Returned & Response Rate (\%) \\
\hline $\begin{array}{l}\text { SNNPRS Bureau of Water Resource } \\
\text { Development }\end{array}$ & 2 & $=$ & 100 \\
\hline $\begin{array}{l}\text { SNNPRS Natural Resource and } \\
\text { Environmental Protection Authority }\end{array}$ & 12 & 12 & 100 \\
\hline Hawssa City Municipality & 12 & 12 & 100 \\
\hline $\begin{array}{l}\text { Hawassa City Natural Resource and } \\
\text { Environmental Protection Office }\end{array}$ & 12 & 8 & 67 \\
\hline Total & 48 & 44 & 92 \\
\hline
\end{tabular}

Source: Field survey, 2013

A total of 48 questionnaires were purposively given to selected four public sector's experts. As the above table illustrates of the total 48 questionnaires distributed to four public institution's experts about $(100 \%)$ response rate was achieved in three sectors. But from Hawassa City Natural Resource and Environmental Protection Office (67\%) of the questionnaires returned and analyzed. Therefore, as presented in table 1 response rate of the total 48 questionnaires distributed about $44(92 \%)$ response rate were achieved. In addition, five interviews were made with key informants and 32 focus group discussions were conducted with stakeholder groups of MSE, NGOs and CBOs.

\subsection{Demographic Data of Respondents}

For this study demographic indicators mainly level of education and sex of respondents were analyzed.

Table 2. Sex and Educational Level of Respondents by Sector.

\begin{tabular}{|c|c|c|c|c|c|c|}
\hline \multirow{2}{*}{ Sector } & \multicolumn{3}{|l|}{ Sex } & \multicolumn{3}{|c|}{ Level of education } \\
\hline & Male & Female & Total & Degree & Masters & Total \\
\hline SNNPRS Bureau of Water Resource Development & 8 & 4 & 12 & 10 & 2 & 12 \\
\hline SNNPRS Natural Resource and Environmental Protection Authority & 9 & 3 & 12 & 8 & 4 & 12 \\
\hline Hawassa City Municipality & 8 & 4 & 12 & 12 & 0 & 12 \\
\hline Hawassa City Natural Resource and Environmental protection Office & 7 & 1 & 8 & 8 & 0 & 8 \\
\hline Total & 32 & 12 & 44 & 38 & 6 & 44 \\
\hline
\end{tabular}

Source: Field Survey, 2013

Table 2 shows that out of 44 respondents $32(73 \%)$ were male while about $12(27 \%)$ were female respondents. This implies that the majority (73\%) of the selected public institution experts were male. In terms of educational background, more than half of the respondents, 38 (86\%) graduated from universities/ colleges holding undergraduate degree and the rest six (14\%) were Master degree holders. Hence, the result indicates, that majority of the experts in the selected public institutions have their first degree. This implies that in the level of education those selected public institutions have trained human resource which could play their important role in the management of Lake Hawassa.

\section{Discussion}

\subsection{Institutional Framework for Management of Lake Hawassa}

Creating responsible institutional framework is one of the key tools for effective management of lake resource. Water management is a responsibility shared by wide range of institutions but the mandates differ among institutions. The issue that who manages lake resource and their institutional arrangement should be considered for sustainable development. To effectively manage lake resources institutional frameworks and their capacities are important for successful lake management (GWP, 2012). Thus, in order to assess the institutional frameworks, the researcher used primary and secondary sources. First, questionnaires were distributed to sample population to make persuaded about effective institutional frameworks for Lake Hawassa as indicated below in figure 1 .

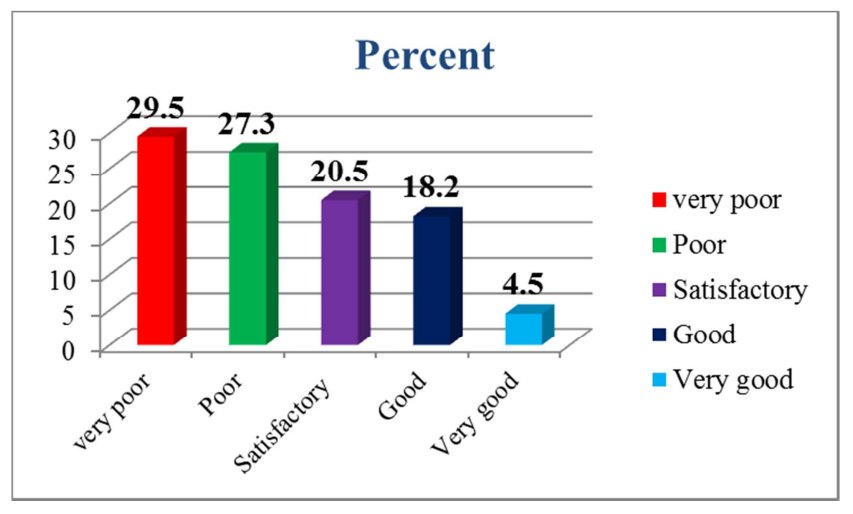

Source: Field survey, 2013

Figure 1. Results for Effective Institutional Framework.

Figure 1 indicates percent of response rate describing about effective institutional frameworks to manage Lake Hawassa. The result obtained from respondents provides that about (29.5\%) and (27.3\%) said very poor and poor respectively on the existing institutional frameworks. About $(20.5 \%)$ of respondents views that the existing institutional 
structure is satisfactory and $(18.2 \%)$ of the respondents response were good. Only $(4.5 \%)$ of respondents indicated that existing institutional framework is very good to effectively manage the lake. In the aspect of effective institutional structure majority $(87 \%)$ of the respondents indicated two main reasons. Accordingly, the first reason they mentioned was lack of established River Basin Organization for Lake Hawassa and the second reason was that there is weak structure of Regional Environmental Protection Organ in SNNPRS.

In addition, to check inconsistencies interviews conducted with key informants and the interviewers mentioned that based on the proclamation No.534/2007 River Basin Councils and Authorities Proclamation Lake Hawassa is under the Rift Valley Lakes Basin. However, still there is no established river basin authority for Lake Hawassa.

Therefore, the finding implies that there is an institutional limitation to successfully manage Lake Hawassa. Hence, it is better to examine and interpret the institutional frameworks from both water and environmental sectors.

The MoWR (1999) water policy of Ethiopia provides that lakes should be managed in the context of their surrounding river basin. The policy also ensures that management of water resources to be at lowest and most efficient level of institutional set up, which provides for the full participation of users and promotes effective decision making at the lowest practical levels under (RBO). The critical issue in this regard is that the Ethiopian water policy was issued since (1999) almost fourteen year back. Further, Ethiopian River Basin Councils and Authorities Proclamation were issued in 2007 (Proclamation No. 534/2007). The Proclamation seems to be expected as a framework or enabling legislation for the establishment of RBOs for each river basin of the country by subsequent subsidiary legislation. However, there is no established River Basin Organization to manage Lake Hawassa. This implies weak enforcement of polices and legislative provisions in the country and issue of institutionalized lake resource management got little priority but the level of degradation of Lake Hawassa is high due to its location to rapidly growing urban vicinity and other related anthropogenic influences.

In many countries of the world lake management activities is first supported by public institutional structure. This is because public institution can design and establish approaches and principle for integrated lake management. Whenever there is no responsible public institution, which undertakes the overall management mechanism, achieving successful lake management becomes in question (WBI, 2006).

For example, in Uganda the Local Government Act of 1997 decentralized policy and legislation devolved responsibility for the management of natural resources to the districts, with an advisory and monitoring role for Wetlands Inspection Division (Nunanetal, 2003).

Secondly, The Ethiopian Environmental Protection Authority was established since 2002 by proclamation No. $295 / 2002$ with the objective of formulating policies, strategies, laws and standards to ensure social and economic development activities in the country sustainably enhance human welfare and safety of the environment. Under this proclamation of part three (Art. 15) provides the regional states to establish or designate their own regional environmental organs, with responsibility for conducting, formulation, implementation, review and revision of regional conservation strategies; and for environmental mentoring, protection and regulation. Based on this SNNPRS established Environmental Protection, Land Administration and Utilization Authority by proclamation No.52/2003. According to this proclamation the authority has given different power and duties such as to 'prepare regional environmental laws and strategies, enforce private investors to conduct EIA, establish systems to carry out EIA of the regional development projects, policies and strategies. But this institutional structure is currently restructured as Natural Resource and Environmental Protection Authority with its accountability to the Regional Agriculture and Rural Development Bureau. In the Natural Resource and Environmental Protection Authority the environmental protection organ was structured to Land Administration, Use and Environmental Protection core process as Environmental and Biodiversity Case Team with only seven experts to deal with environmental protection issues.

However, various duties and responsibilities regarding the environment is given to the case team and different development actives are taking place near to Lake Hawassa, so how can this small case team can develop regional environmental laws and conduct environmental impact assessment for regional projects. That is why still in the SNNPRS there are no regionally established EIA and pollution control proclamation and the region uses the federal EIA laws this also explains that the existing institutional framework of the region influences the power and duties of the organization. In the same proclamation of part two (Art.17) states that the institution has power and duties 'to carry out studies to control pesticides, herbicides and other different medicines that pollute discharging into soil, lakes and rivers and in general to control their negative impacts on environment and natural resources and enforce the concerned organs to take correction measures'. Therefore, the issue is that how this case team can execute effectively those power and duties given in the proclamation. However, the institutional structure of environmental protection organ in the other regions of Ethiopia is also different from the structure of SNNPRS. For example let us see the institutional structure of environmental organ of Amhara, Oromiya and Tigray regions.

In Amhara region, the environmental affairs are now handled by the Environmental Protection, Land Use and Administration Authority. This authority has three units, that is, Ensuring Sustainable Environmental Protection Core Process, Land Use Core Process, and Land Administration Core Process. From the three processes the one that deals with environmental matters is the Ensuring Sustainable Environmental Protection Core Process, which is accountable 
to the head of the authority, which, in turn, is accountable to the region's president. In Oromiya Regional State, environmental protection organ was first established in 1993 as the Natural Resources Development and Environmental Protection Bureau. In 2009, the Environmental Protection Office was merged with Land Use and Planning Office, which was dealing with land issues in particular granting of title deed to investors, and know, became Oromiya Land and Environmental Protection Bureau. Thus, environmental matters are now handled by the Environmental Protection Core Process. In Tigray, the environmental protection organ was established in 2004 as Environmental Protection, Land Administration and Use Authority (Dejene, 2012).

From the above it is better to understand that those three regions have independent environmental protection organ. In line with this those regions have established their own regional EIA and pollution control laws, which is not established in the SNNPRS.

The situation is also somewhat different in other countries. For instance, in Uganda as illustrated in the literature part, for sustainable management of environment there are various national, regional and local institutions established in the country with power and responsibility to manage their natural environment. The Uganda National Environmental Management Authority and Wetland Inspection Division were established for natural resource management, which is further decentralized to districts with duties to manage environment.

\subsection{Legislative Provision in SNNPRS for Water Resource Management}

Safeguarding through legislative provisions and their effective implementation is one of the key mechanisms to protect natural resource from depletion. Based on this, the next sub-section outlines some of the legislative provisions in SNNPRS related to environment and natural resources, which have direct or indirect importance in the management of lake.

The Constitution of SNNPRS: "As the supreme law of the Regional Sate, all subsidiary laws or implementing legislation issued subsequently must be consistent with the regional constitution". The SNNPRS revised constitution of (2001) addressed environmental issues in various articles such as article 43, 44,117 and 120. Article 117(5) says that "the government shall the responsibility to hold, on behalf of the people, land and other natural resources in order to deploy them for their common benefit and development". So the constitution guarantees the ownership of land and other natural resources including lakes under public. Article 120 (4) directs fundamental duties for every citizen of the state and government to protect their environment. According to this article the residence and the government have to protect their environment for sustainable development. Also Article 120 (3) provides that "people have the right to full consultation and to express of views in planning and implementation of environmental policies and projects that affects them directly".
Thus, in the SNNPRS there is a constitutional basis for environmental management. The constitution recognized the right of citizens to be participated in the natural resource management. Also in the constitution citizens and government have duties to protect their environment.

Sectoral Legislative Provision Related to Lake Management: It has been recognized that water resource like lake is related to other natural resource such as land, investment and forests. The diverse economic actions have greatest impacts on water resources. Hence, integrating lake management into laws, regulations and decision-making procedures in such sectors is fundamental. This sub-section describes specific regional land, fishery and forest laws of SNNPRS, which is directly or indirectly significant to lake management.

Land Proclamation: The SNNPRS have established regional rural land laws in 2007. The Rural Land Administration and Utilization Proclamation of the region (Proclamation № 110/2007), for example, recognizes the rights of private investors to get rural land for investment, with priority given to peasants and pastoralists (Art. 5(15). and Art. 10(5) of the proclamation further stipulate that the development plan submitted by investors looking for land must not lead to the degradation of the land or surrounding environment). Further, it requires investors to sustainably manage their holding, including any and all natural resources there (Article 10(6)). While the rural land law of the SNNPRS also orders that the development plan that investors present to obtain rural land must not lead to land or environmental degradation.

Forest Proclamation: The SNNPRS Forest Management, Development and Utilization Proclamation No. 77/2004 part two (Art.6) states that "when the region finds it necessary to develop and conserve any kind of tree species, bushes and other plants, it can classify them as reserve forest to; harness shores of water bodies and river basins and avert soil erosion." The proclamation part four (Art.11) also encourages the participation of local community and women's of the regions in forest conservation, development and utilization.

Fishery Proclamation: The SNNPRS government endorsed fishery legislation with an outlook to guarantee management, development and control of fishery resources in the region (Proclamation No. 78/2004). The regional fishery proclamation seeks to enhance the supply quality of fish products, enable the society and government to fully relish the products and protect the resources from the depletion. This proclamation gives foremost attention to fishery resource management and development.

In generally, the above are some of the legislative provisions issued in the SNNPRS related natural resources management. However, for sustainable management of natural resources such as lakes, other legislative provisions are needed like EIA, Pollution control, and investment laws which are not endorsed in the SNNPRS and the regional state uses the federal proclamation and there is also weak enforcement of the federal laws. For instance, according to 
the key informant there are different hotel investments to the shore of Lake Hawassa except Haile Resort other hotel projects were constructed without EIA process.

The other problem regarding legislative provision is weak implementation of the Federal Pollution Control Proclamation. The Proclamation No. 300/ 2002 (Art.5) states that 'when any activity poses a risk to human health or to the environment, the authority or the relevant regional environmental agency shall take any necessary measure up to the closure or relocation of any enterprises in order to prevent harm. However, the implementation of this proclamation is not common. For instance, in the focus group discussion participants complains the current location of Hawassa Textile Factory and Hawassa Hospital due to their nearby to the lake. They also argue that there is discharge from the hospital and factory to the lake and still no measure were taken from the government. Therefore, the result illustrates that there is gaps in the legal frameworks to manage Lake Hawassa.

However the situation related to lake management in other countries is rather different. For example, in Uganda lake management as described in the literature part is first supported by different regulations and directives. Scholar like Oliver (2004) also advocates, establishing new legal frameworks and implementing the existing laws as important instrument for successful management of lake resources. According to GWP (2012) law reforms, through the introduction of new frameworks or upgrading the existing one is seen as a priority for water and environment managements for the upcoming years.

\subsection{Financial Mechanism to Manage Lake Hawassa}

Finance is a significant factor for any environmental management. It is also true that lake management demands enormous budget for various reasons. Successful lake management needs adequate technology, consultancy of skilled man power and uses of various communication tools which all requires enormous budget.

Table 3. Descriptive Statistics for Innovated Financial Mechanisms.

\begin{tabular}{llll}
\hline Variable & Results & Frequency & Percent \\
\hline \multirow{2}{*}{ Grant and loan for lake } & Yes & 32 & 72.7 \\
management & No & 12 & 27.3 \\
& Total & 44 & 100 \\
\multirow{3}{*}{ Water pollution charge system } & Yes & 17 & 38.6 \\
& No & 17 & 38.6 \\
& Not know & 10 & 22.8 \\
& Total & 44 & 100 \\
\hline
\end{tabular}

Source: Field survey, 2013

In table 3 on the practice of innovated financial mechanism especially, pollution charging system (38.6\%) of respondent provided 'Yes' there is pollution charging mechanism and $(38.6 \%)$ of the respondent said 'No' and the rest $(22.8 \%)$ do not know the practice of pollution charge in case of Lake Hawassa. Also the respondents were asked to give their views on grant and loans to Lake Hawassa management. Table 3 above point out that $(72.7 \%)$ of respondents understood there were grants and loan from the development partners such as UNDP and GEF while (27.3\%) said there were no grants and loan for lake management.

As the information gathered from the key informants, the Hawassa City Administration allocates budget for Lake Hawassa management in terms of some sectors especially Hawssa City Municipality, Hawassa City Natural Resource and Environmental Protection, and Culture and Tourism Offices.

Also to minimize existing information gap the researcher interviewed government officials about the practice of water pollution charge and the interviewer provided that still there was no organized practices of water pollution charge system, however, there is system of revenue collection from the lake side business to raise local funds.

In the focus group discussion, respondents viewed that there is good mechanism of raising local fund around "Amoral Gedel" recreational centers from eco-tourism project through service charge like entrance fee, weeding ceremony and in turn they conserve and preserves the lake and its surrounding environment. But this system of management is limited to the specific area and the responsible implementing organ is also non-governmental organization called Sidma Development Association.

In generally, the common financial mechanisms used to manage Lake Hawassa, were government budget, donation, loan and local revenue system. But, the experiences of other developing countries were dissimilar. For example lake management in Kenya and Uganda follows multidimensional financial mobilization mechanisms and the management project is supported by government budget, pollution charge, and revenue collection, local and international funds.

\subsection{Technological Resources to Mange Lake Hawassa}

Technological capacities are necessary for sustainable management of natural resources. The uses and application of adequate technological tools with in public institutions influences day to day activities of experts and managers, which in turn helps for efficiency and success of organization in the management of lake resources.

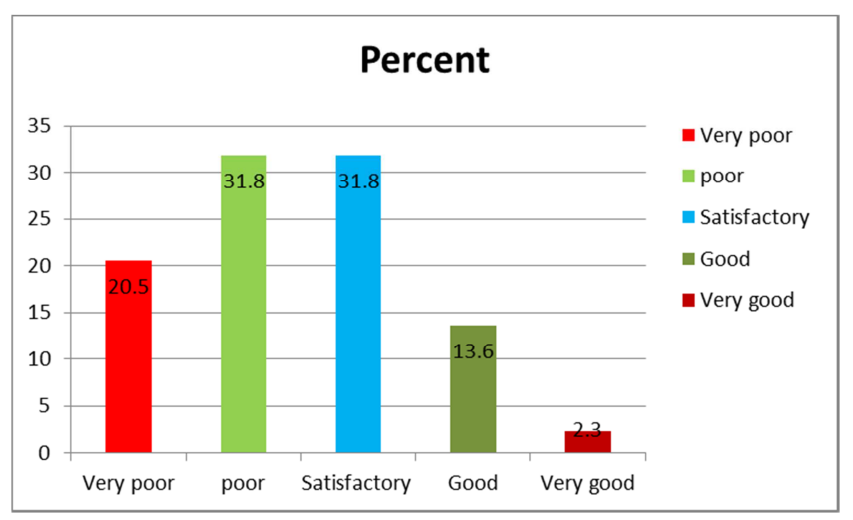

Source: Field survey, 2013

Figure 2. Result on the Technological Interventions. 
As shown in the figure 2 respondents provided that $(20.5 \%)$ very poor, $(31.8 \%)$ poor, $(31.8 \%)$ satisfactory, $(13.6 \%)$ good and only $(2.3 \%)$ very good on the technological interventions to manage Lake Hawassa. Thus, respondent views that intervention of technical tools regarding Lake Hawassa was low.

For the same issue, key informants were asked to give their outlook on technological interventions. Based on this the SNNPRS Water Bureau and Natural Resource and Environmental Protection Authority use geographic information systems for natural resource management. In Hawassa City Natural Resource and Environmental Protection there is no practice of using geographic information system as that the institution was recent in its establishment. For their response respondents suggest that lack of water and environmental laboratories, poor data base system and absence of sewerage treatment systems have influence on the lake management.

The key informants also argues that Lake Hawassa is located within fast growing urban areas as result, solid and liquid wastes from various sources influence natural systems of the lake. Therefore, municipality has to use different waste treatment mechanism to protect the lake pollution but the practice is not well ongoing. The key informant for instance, express that still Hawassa City Municipality have no means of developed sewerage system and hazardous treatment mechanism and for this reason all the liquid waste system ends to the lake.

\subsection{Integration of Stakeholders in Management of Lake Hawassa}

Management of water resource requires multiple- level and cross- sectoral integration and linkages. Lake management in its dual nature involves integration among various sectors and with other stakeholders.

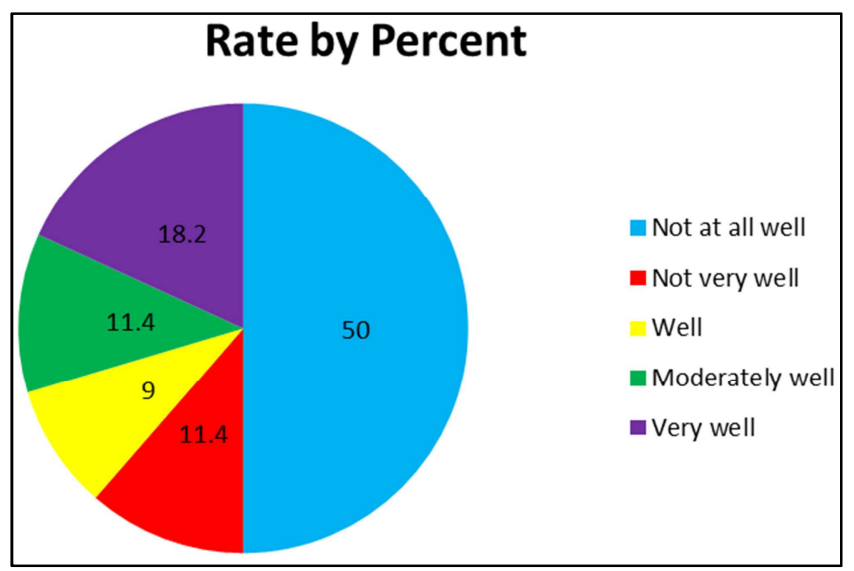

Source: Field survey, 2013

Figure 3. Response Rate for Integration of Stakeholders.

Figure 3 illustrates the observation of respondents concerning stakeholder's integration to manage Lake Hawassa. From the sample respondents $(50.0 \%)$ provided not at all well, (11.4\%) not very well and (9\%) well about the stakeholders combination. The rest $(11.4 \%)$ moderately well and $(18.2 \%)$ given very well as the current combinations of stakeholders particularly NGOS, MSE and CBOs.

Based on this, the finding of the study verifies that there is a weak linkage among government sectors and stakeholders in the management of the lake. Unless strong integration how it can be possible to achieve the desired goals.

On the other hand, scholars strongly advocate for strong stakeholders integrations. For instance, GWP (2012) explains that fragmented framework for lake management cannot meet the inter-relationships among the sectors. The idea is that lake management should be integrated into various sectors and stakeholders in joint approach. The Ethiopian Environmental Protection Organ establishment proclamation No.295/2002 states that EPA has power and duties 'in consultation with the competent agencies, propose incentives or disincentives to discourage practices that may hamper the sustainable use of natural resources or the prevention of environmental degradation or pollution'. This means that environmental protection sector ought to be involved and consulted in the issues of natural resource management and investment projects implementation. However, these kinds of practices of sectoral integration during investment project in the study area are infrequent.

However, experiences of some other developing countries show that stakeholder combination as the key component for sustainable management of lake resources. For example, one of the successful lake management of Uganda as indicated in literature part Nunanetal (2003) used three approaches of integration to Lake George:

First they used inter-district integration including bringing all three levels of local government (Parish, Sub-county and District) together from three districts;

Secondly followed inter-sectoral, involving sectors such as fisheries, environment, water, wetlands and community development, to provide a holistic approach to lake management, recognizing the interrelatedness of the system and livelihoods; and

Finally inter-stakeholder, bringing together many types of stakeholders all concerned with the improved and sustainable use and management of Lake George basin resources for improved livelihoods.

\section{Conclusions}

Public institution and its capacity play a fundamental role in the management of lake resources. The aim of this research has been to review the institutional aspect in the management of Lake Hawassa. Based on this the following significant issues come out as result of this study.

The study assessed the institutional framework in an attempt to probe deeply into their capacity in the management of the lake. In this the study identified public institutional structure drawbacks to successfully manage Lake Hawassa. It can be concluded that the foremost institutional structure weakness are associated with absence of responsible river basin organization to manage the lake 
and the continued restructuring of environmental protection sector in the study area.

The study explored limitations in the enforcement of the legislative provision like establishment of river basin organization and water regulation proclamations. The study has also found out that there is also absence of regionally established EIA, pollution control and investment laws.

The study investigated whether the capacity of local public institutions towards lake management are affected by human resource dimensions of the way these institutions select, utilize and train. The study found under utilization of staffs within the selected institutions. The financial mechanisms used to manage Lake Hawassa were poor due its limited financial mobilization systems and the method is mainly targeted government budget and funds. In turn there is no means of using polluter pay principle to raise local fund and the local revenue collection mechanisms from lake side business were also poor.

The capacity of institutions to use technology for management of the lake is inadequate. These emanated due to lack of sewerage and hazardous treatment, deficiency of water information system, lack of environmental database system and inadequate financial resources to afford technological inputs.

The result of the study also showed that there is weak integration among government sectors and stakeholders for sustainable management of the lake. The lower combination between the environmental sector and investment sector is also constraints for the management of the lake in the study area.

\section{Acknowledgements}

Thank Almighty God for eternity being with me in all my dealings and giving patience to complete my study.

I have obtained special ranges of support from various people in path of producing this paper. First and foremost especial appreciation goes to my advisor Dr. Samson Kassahun, and thank for your unlimited support, guidance, encouragement, scholarly criticism and the learning opportunity given during the research.

This thesis is dedicated to my grandfather Felho Mogiso and grandmother Workinesh Dedu for sending me to the school at my young age while my age mates are in the locality were retained to help their parents in the agricultural field. And my genuine thanks also goes to my father Faris Felho for your fatherhood leadership played essential in my academia. Finally, my credits go to every people who were involved in the interview, focus group discussion and those responded to the questionnaires for devotion of their time and energy.

\section{Abbreviations and Acronyms}

$\begin{array}{ll}\text { AAU } & \text { Ababa University } \\ \text { BoFED } & \text { Bureau of Finance and Economic Development } \\ \text { CBO } & \text { Community Based Organization } \\ \text { CSA } & \text { Central Statistical Agency of Ethiopia } \\ \text { GEF } & \text { Global Environmental Facility } \\ \text { EFY } & \text { Ethiopian Fiscal Year } \\ \text { EIA } & \text { Environmental Impact Assessment } \\ \text { EPA } & \text { Environmental Protection Authority of Ethiopia } \\ \text { EWNHS } & \text { Ethiopian Wildlife and Natural History Society } \\ \text { FDRE } & \text { Federal Democratic Republic of Ethiopia } \\ \text { FGD } & \text { Focus Group Discussion } \\ \text { GTP } & \text { Growth and Transformation Plan of Ethiopia } \\ \text { GWP } & \text { Global Water Partnership } \\ \text { IDGEC } & \text { Institutional Dimensions of Global Environmental Change } \\ \text { IHDP } & \text { International Human Dimension Program } \\ \text { IUCN } & \text { International Union for Conservation of Nature and Natural Resource } \\ \text { IWRM } & \text { Integrated Water Resource Management } \\ \text { LGBIMO } & \text { Lake George Basin Integrated Management Organization } \\ \text { MoWR } & \text { Ministry of Water Resource of Ethiopia } \\ \text { MSE } & \text { Micro and Small Scale Enterprises } \\ \text { NEMA } & \text { National Environment Management Authority of Uganda } \\ \text { NES } & \text { National Environment Statute of Uganda } \\ \text { NGO } & \text { Non-Governmental Organization } \\ \text { RBO } & \text { River Basin Organization } \\ \text { SNNPRS } & \text { Southern Nations, Nationalities and Peoples Regional Sate } \\ \text { UN } & \text { United Nations } \\ \text { UNCH } & \text { United Nations Centre for Human Settlements } \\ \text { UNDP } & \text { United Nations Development Program } \\ \text { UNESCO } & \text { United Nations Educational, Scientific, and Cultural Organization } \\ & \end{array}$




$\begin{array}{ll}\text { UNU } & \text { United Nations University } \\ \text { WBI } & \text { World Bank Institute } \\ \text { WID } & \text { Wetlands Inspection Division of Uganda } \\ \text { WWC } & \text { World Water Council }\end{array}$

\section{References}

[1] Amare Lemma. (2005). Site Action Plan for Conservation and Sustainable Use of Lake Hawassa Biodiversity (Rift Valley Lakes Project). Institute of Biodiversity Conservation. [Accessed 18 November, 2012]. http://www.ibc.gov.et/wpcontent/plugins/download.../download.php?id.

[2] Amir, I. (2003). Understanding Institutional Capacity of Local Government Agencies in Indonesia. Australian National University. [Accessed 11 December, 2012].www.academia.edu/.../Understanding_institutional_cap acity_of_local_go.

[3] Bhagavan, M. R. \& Virgin, I. (2000). Generic Aspects of Institutional Capacity Development in Developing Countries. Stockholm Environment Institute.

[4] Bo FED. (2013). The 2012/2013 Allocated Government Budget of SNNPRS. (Unpublished).

[5] Braus, J. (1993). Environmental Education in the Schools. Washington. North American Association for Environmental Education.

[6] CSA. (2010). The 2007 Population and Housing Census Results of Ethiopia: Population Size and Characteristics. Addis Ababa. CSA.

[7] DejeneGirma.(2012). Environmental Impact Assessment in Ethiopia: Laws and Practices. Addis Ababa. AAU.

[8] Demelash Amare. (2008). Assessment of Non-Point Source Pollution in Lake Awassa Watershed Using the Annualized Agricultural Non-Point Source. Addis Ababa. AAU.

[9] EPA. (2003). State of the Environment Report of Ethiopia. EPA. Unpublished.

[10] EWNHS. (1996). Important Birds Areas of Ethiopia: First Inventory. Addis Ababa. EWNHS.

[11] FDRE. (1995). Constitution of the Federal Democratic Republic of Ethiopia. Addis Ababa. FDRE.

[12] FDRE. (2000). Ethiopian Water Resource Management Proclamation, No. 197/2000, Federal Negarit Gazeta. Addis Ababa: Berhanena Selam Printing Press.

[13] FDRE.(2002). Environmental Impact Assessment Proclamation, No. 299/2002, Federal Negarit Gazeta. Addis Ababa: Berhanena Selam Printing Press.

[14] FDRE. (2002). Environmental Protection Organs Establishment Proclamation, No. 295/2002, Federal Negarit Gazeta. Addis Ababa: Berhanena Selam printing Press.

[15] FDRE. (2002). Environmental Pollution Control Proclamation, No. 300/2002, Federal Negarit Gazeta. Addis Ababa: Berhanena Selam Printing Press.

[16] FDRE. (2007). River Basin Councils and Authorities Proclamation, No. 534/ 20007, Federal Negarit Gazeta. Addis
Ababa: BerhanenaSelam Printing Press.

[17] FDRE. (2010). Growth and Transformation Plan of Ethiopia. Addis Ababa. FDRE.

[18] Fekahmed Negash. (2011). Managing Water for Inclusive and Sustainable Growth in Ethiopia: Key Challenges and Priorities. Mo WR. [Accessed 10 November, 2012). http://erdreport.eu/erd/report.../dev-1100111researchpapers_negash.pdf.

[19] GWP. (2012). Integrated Water Resources Management: Adaptive Tool for Building Sustainability and Climate Resilience. [Accessed 16 march, 2013).

[20] Hilderbrand, M. E. and Grindle, M. S. (1994). Building Sustainable Capacity: Challenges for the Public Sector. Harvard Institute of International Development. Cambridge.

[21] Hope, K. R. (1987). Administrative Corruption and Administrative Reform in Developing Countries: Corruption and Reform.

[22] IDGEC. (1999). Institutional Dimensions of Global Environmental Change. Bonn. IHDP.

[23] James, M. Acheson. (2006). Institutional Failure in Resource Management. University of Maine.[ Accessed 20 January, 2012]. http://www.annualreviews.org Journals Anthropology Volume 35, 2006.

[24] Jaspers, F. G. W. (2003). Institutional Arrangements for Integrated River Basin Management. Amsterdam: IWA Publishing.

[25] Kothari, C. R. (1990). Research Methodology: Methods and Techniques (2 ${ }^{\text {nd }}$ Ed.). New Delhi: New Age International Publishers.

[26] Mo WR. (1999). Ethiopian Water Resources Management Policy. Addis Ababa. Mo WR.

[27] Mo WR. (2010). Rift Valley Lakes Basin Integrated Resource Development Master Plan Study Lake Hawassa Sub-Basin Integrated Watershed Management Feasibility study: Vol 1. Addis Ababa. Mo WR.

[28] Mukerjee, A. (2004). The Role of Local Authorities in Lake Management. Bhopal: Vallabh Bhawan. Nnan, F., Musinguzi, K. and Scullin, J. (2003). Integrated management of Lake George, Uganda. LAGBIMO.[Accessed 16 December, 2012). http://www.worldlakes.org/uploads/ELLB\%20George.Nov200 3.pdf.

[29] Oluwu, D. and Smoke, P. (1992). Determinants of Success in Africa Local Government: an Overview. Public Administration and Development.

[30] Oliver, A. (2004). The Role of Public Participation and Citizen Involvement in Lake Basin Management. Central European University. [Accessed 21 January, 2013].

[31] Rebecca, D. (2004). The Role of Communication, Education and Public Awareness in Lake Basin Management. Lake Basin Management Initiative. [Accessed 21 January, 2013]. www.worldlakes.org/uploads/CEPA_draft_22Jun04.pdf. 
[32] Sirgut Mitchel, (2006). Achievements and Challenges in the Implementation of Result Oriented Performance Management system in the Ethiopian Federal Civil Service. Addis Ababa.

[33] SNNPRS. (2001). Revised Constitution of the SNNPRS. Hawassa. SNNPRS.

[34] SNNPRS. (2003). SNNPRS, Environmental Protection, Land, Administration and Utilization Proclamation, No. 52/ 2003, Debub Negarit Gazeta. Hawassa: Berhanena Selam Printing Press.

[35] SNNPRS. (2004). SNNPRS, Forest Management, Development and utilization Proclamation, No. $77 / 2004$, Debub Negarit Gazeta. Hawassa: Berhanena Selam Printing Press.

[36] SNNPRS. (2004). SNNPRS, Fish Resources Management, Development and Control proclamation, No. 78/ 2004, Debub Negarit Gazeta. Hawassa: Berhanena Selam Printing Press.

[37] SNNPRS. (2007). SNNPRS, Rural Land Administration and Utilization Proclamation, No. 110/2007, Debub Negarit Gazeta. Hawassa: Berhanena Selam Printing Press.

[38] UNCHS. (1997). Partnership in the Water Sector for Cities in Africa: Report of Cape Town Consultations. Nairobi. UNCHS.
[39] UNDP. (2007). Capacity Assessment Practice Note. UNDP. [Accessed 9 December, 2012). http:www.undpalm.org/sites/default/.../pn_capacity_development1.pdf.

[40] UNEP. (2012). Integrated Water Resources Management Planning Approach for Small Island Developing States. UNEP.

[41] UNESCO. (2004). National Water Development Report for Ethiopia Final. UNESCO. [Accessed12 December, 2012). http://waterwiki.net/images/4/41/ethiopiafull.pdf.

[42] UNU (2011). Transboundary Lake Basin Management: Laurentian and African Great Lakes. Ontario. UNU.

[43] WBI. (2006). Integrated Water Resources Management: Introduction to Principles and Practices. WBI. [Accessed March, 2013). http://www.pacificwater.org/.../IWRM/.../introduction $\% 20$ to $\%$ 20iwrm/IWRM.

[44] Yemane Gebreegziabher. (2004). Assessment of Water Balance of Lake Hawassa Catchment. MSc Thesis. International Institute for Geo-Information Science and Earth Observation Enschede. Netherlands. 